\title{
PENYULUHAN BANTUAN HIDUP DASAR PADA SISWA/I DI SMA YAYASAN ANASTASIA PANCUR BATU KABUPATEN DELI SERDANG
}

DOI: https://doi.org/10.33024/jkpm.v4i5.4179

\author{
Rotua Elvina Pakpahan ${ }^{1 *}$, Lindawati Simorangkir ${ }^{2}$, Agustaria Ginting ${ }^{3}$, \\ Mardiati Barus ${ }^{4}$, Lindawati Tampubolon ${ }^{5}$, Murni Sari Dewi Simanullang ${ }^{6}$, \\ Mestiana Br Karo7, Vina Yolanda Sigalingging ${ }^{8}$
}

1,2,3,4,5,6,7 Prodi Ners STIKes Santa Elisabeth Medan

Disubmit: 07 Maret 2021 Diterima: 21 Mei $2021 \quad$ Diterbitkan: 30 September 2021

Email korespondensi: rotuaelvina@gmail.com

\begin{abstract}
ABSTRAK
Kesehatan yang prima akan di dapatkan ketika tubuh mendapatkan oksigen yang baik. Henti nafas diakibatkan melemahnya kerja jantung sampai dengan terhentinya kerja jantung dan dapat mengakibatkan tidak terpenuhinya oksigen dalam tubuh yang artinya kebutuhan dasar hidup tidak dapat terpenuhi. Tujuan dari penyuluhan bantuan hidup dasar adalah meningkatkan pengetahuan dan dapat melakukan tindakan secara mandiri untuk pertolongan bantuan hidup dasar di lingkungannya. Sasaran kegiatan ini adalah siswa/i SMA Yayasan Anastasia Pancur Batu. Metode yang digunakan dalam penyuluhan bantuan hidup dasar ini adalah dengan melakukan presentasi materi dan melakukan simulasi bantuan hidup dasar. Hasil dari kegiatan ini adalah siswa/i mempu mengetahui tentang dasar-dasar pemberian bantuan hidup dasar dan mampu melaksanakan pemberian bantuan hidup dasar di lingkungannya. Diharapkan dengan dilaksanakannya penyuluhan ini, pada siswa/i dapat sigap dan mampu memberikan bantuan hidup dasar guna memperkecil angka kematian.
\end{abstract}

Kata Kunci : Bantuan Hidup Dasar, Penyuluhan Kesehatan

\begin{abstract}
Excellent health will be obtained when the body gets good oxygen. Stopping breathing is caused by the weakening of the work of the heart to the cessation of the work of the heart and can result in not meeting oxygen in the body, which means that the basic needs of life cannot be fulfilled. The purpose of basic life support extension is to increase knowledge and be able to take action independently for basic life support assistance in their environment. The target of this activity is SMA Anastasia Pancur Batu Foundation. The method used in this basic life support extension is to present the material and perform basic life support simulations. The result of this activity is that students are able to know the basics of providing basic life support and are able to provide basic life support in their environment. It is hoped that with the implementation of this counseling, students can be alert and able to provide basic life support in order to reduce the mortality rate.
\end{abstract}

Keywords: Basic Life Support, Health Education 


\section{PENDAHULUAN}

Indonesia merupakan negara yang memiliki tingkat kecelakaan yang cukup tinggi. Kecelakaan lalu lintas merupakan suatu masalah yang membutuhkan penangana serius. Kecelakaan lalu lintas menjadi penyebab kematian nomor tiga di Indonesia setelah serangan jantung dan Tuberculosis (TBC). Kematian dapat terjadi karena ketidakmampuan petugas daam menangani penderita fase gawat darurat. Keadaan gawat daruratan merupakan suatu keadaan klinis dimana pasien membutuhkan tindakan medis segera untuk menyelamatkan nyawa dan kecacatan lebih lanjut (Agustini, dkk., 2017).

Tindakan dalam penekanan angka kematian dilakukannya Basic Life Support atau dalam bahasa Indonesia dikenal dengan Bantuan Hidup Dasar (BHD) adalah segala usaha yang dilakukan untuk dapat mempertahankan kehidupan pada saat seorang mengalami kondisi kegawatdaruratan yang mengancam jiwa (AHA, 2015). Bantuan Hidup Dasar (BHD) berupa Resusitasi Jantung Paru (RPJ) harus diberikan kepada setiap orang yang mengalami kegawatdaruratan seperti pendarahan, henti nafas dan henti jantung. Sehingga, sangat diperlukan untuk mengajarkan mengenai keterampilan BHD pada siapa saja terutama orang dewasa.

Peningkatan pengetahuan masyarakat dalam upaya pemberian pertolongan pertama pre hospital perlu dilakukan. Masyarakat yang tidak paham tentang pemberian pertolongan pertama akan censerung memberikan pertolongan seadanya tanpa memikirkan tindakan yang dilakukan itu tepat atau tidak. Selain itu, masyarakat awam biasanya hanya menunggu tim penolong datang tanpa memikirkan bagaimana kondisi korban yang akan ditolong padahal masyarakat awam dikatakans ebagai penolong pertama dan utama. Data diatas diperkuat oleh keterangan tenaga medis pada salah satu rumah sakit di kota Denpasar. Kebanyakan pasien dibawa ke rumah sakit belum mendapatkan penanganan awal dan dengan cara transportasi yang kebanyakan menyalahi aturan yang semestina (Dhayana, 2015).

Penyuluhan dan pelatihan merupakan upaya yang penting dilakukan untuk meningkatkan pengetahuan dan keterampulan masyarakat awam dalam memberikan pertolongan pre hospital. Penyuluhan dan pelatihan ini baik diberikan sejak usia muda untuk menciptakan generasi muda yang berkompeten dalam mengaplikasikan serta mensosialisasikan cara untuk memberikan pertolongan pre hospital (Agustini, dkk., 2017).

\section{MASALAH}

Alasan kami memilih tempat kegiatan ini adalah Yayasan Anastasia merupakan salah satu yayasan yang dalam wilayah kerja PKM Prodi Ners STIKes Santa Elisabeth Medan. Jumlah siswa/i di Yayasan Anastasia Pancur Batu pada tahun 2020 sebanyak 25 orang, dimana terdiri dari siswa laki-laki dan perempuan. Letak wilayah Yayasan Anastasia berada di lingkungan jalan antar kota,dimana banyak terdapat kejadian lalu lintas yang tidak diinginkan. Selain itu wilayah pancur batu juga banyak didapatkan lansia yang menderita hipertensi maupun stroke. 


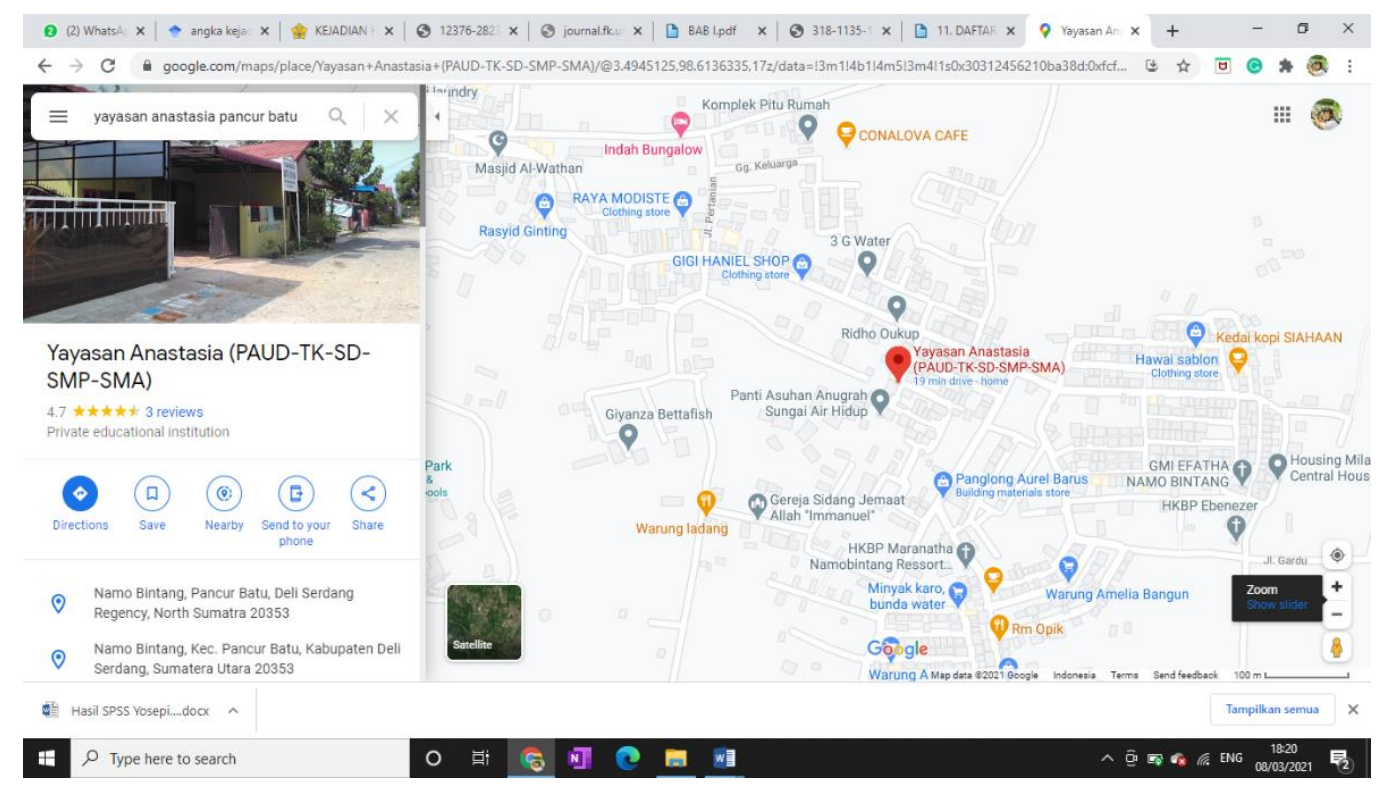

Gambar 2.1. Peta Lokasi Kegiatan Pengabdian Masyarakat

\section{METODE}

a. Tahap Persiapan

Tahap persiapan untuk kegiatan ini dengan membuat pre planning, persiapan pembuatan alat alat eksehaatn yang akan digunakan, persiapan materi seperti PPT dan leaflet, tempat, phantom, LCD, dan lain lainnya yang akan digunakan dalam kegiatan penyuluhan di Yayasan Anastasia Pancur Batu. Perisapan dilakukan mulai dari tanggal 5 - 10 Januari 2020.

b. Tahap Pelaksanaan

Kegiatan penyuluhan ini dilakukan dengan izin oleh Ketua STIKes Santa Elisabeth Medan, kemudian dari Puskesmas Pancur Batu dan dari Yayasan Anastasia itu sendiri dan kemudian dilanjutkan dengan melakukan Penyuluhan BHD.

c. Evaluasi

i. Struktur

Peserta hadir sebanyak 35 siswa di Yayasan Anastasia Pancur Batu. Setting tempat sesuai dengan tempat duduk di kelas untuk pembelajaran sehari-hari. Penggunaan bahasa yang digunakan komunikatif, siswa/I memahami materi yang disampaikan.

ii. Proses

Pelaksanaan kegiatan dimulai pukul 10.00 - 12.00 WIB. Sesuai dengan jadwal yang telah direncanakan.

\section{HASIL DAN PEMBAHASAN}

Metode pelaksanaan dalam kegiatan penyuluhan ini dilaksanakan pada tanggal 13 Januari di Yayasan Anastasia Pancur Batu. Pelaksanaan penyuluhan ini ditujukan pada para siswa.i. media dan alat yang disediakan yaitu : phantom BHD, materi berupa leaflet, PPT, laptop, LCD, pengeras suara, dll. 
Berikut gambar pelaksanaan kegiatan:
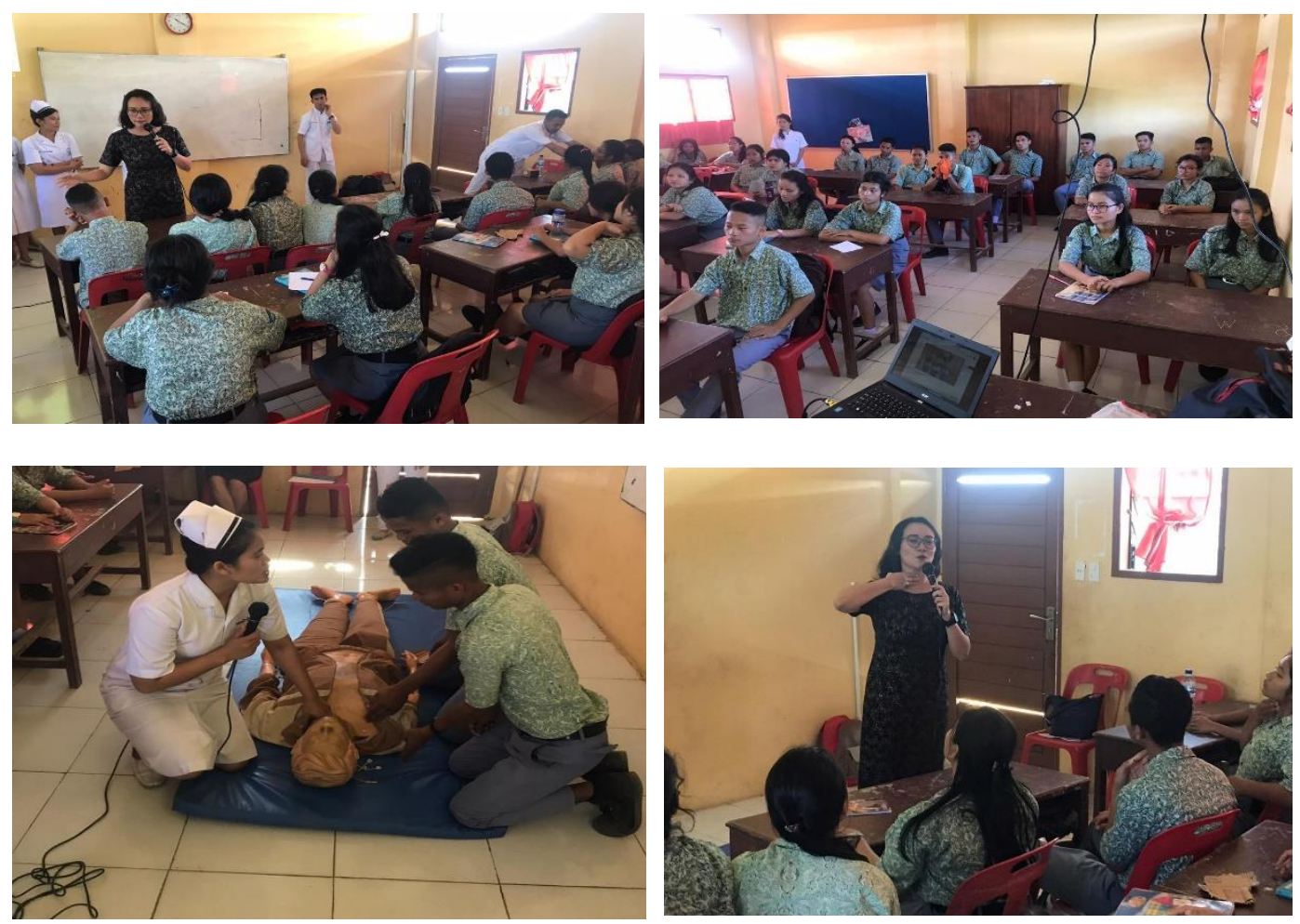

Gambar 4.1 Pelaksanaan Kegiatan Pengabdian Kepada Masyarakat

\section{KESIMPULAN}

Penyuluhan BHD dilaksanakan di Yayasan Anastasia Pancur batu di Wilayah kerja Puskesmas Pancur Batu untuk membantu para remaja siswa/l untuk mengetahui tentang bahaya keterlambatan penanggulangan Bantuan Hidup Dasar, kemudian mengetahui cara pemberian BHD yang tepat cara dan sasaran dengan cara simulasi dan pendidikan tentang BHD.

\section{DAFTAR PUSTAKA}

Agustina, Ni Luh Putu Inca Buntari Agustini., Suyasa, I Gede Putu Darma., Wulansari, Nadya Treesna., Dewi I Gusti Ayu Puja Astuti., Rismawan, Made. (2017). Penyuluhan Dan Pelatihan Bantuan Hidup Dasar.

Alamsyah., Sulasri., Hasinda., \& Handayani, T. (2020). Familiarisasi Bantuan Hidup Dasar Bagi Orang Awam di Desa Romangloe Kecamatan Bontomarannu Kabupaten Gowa. Jurnal Kreativitas Pengabdian Kepada Masyarakat (PkM), 3(1), 39-45. doi: https: / /doi.org/10.33024/jkpm.v3i1.2487

Al Fatih, H. and Rahmidar, L., 2019. Kepuasan dan Kepercayaan Diri Mahasiswa Keperawatan Terhadap Penggunaan Low Fidelity Simulator Dalam Simulasi Bantuan Hidup Dasar. Jurnal Keperawatan BSI, 7(2), pp.153-160. American Heart Association (AHA). 2015. Health Care Research : Coronary Heart Disease. 
Dhayana. (2015). Hubungan tingkat pengetahuan masyarakat tentang tindakan gawat darurat dengan cara penanganan pasien kecelakaan lalu lintas oleh masyarakat di Kota Denpasar. Denpasar: STIKes Bali.

Herlina, S., Winarti, W. and Wahyudi, C.T., 2018. Meningkatkan pengetahuan dan kemampuan kader kesehatan melalui pelatihan bantuan hidup dasar. Riau Journal of Empowerment, 1(2), pp.85-90.

Kemenkes, R.I. (2014). Situasi Kesehatan Jantung. Jakarta: Pusdatin.

Muthmainnah. (2019). Hubungan Tingkat Pengetahuan Awam Khusus Tentang Bantuan Hidup Dasar Berdasarkan Karakteristik Usia Di RSUD X Hulu Sungai Selatan. Healthy-Mu Journal, 2(2), 31-35. doi: https://doi.org/10.35747/hmj.v2i2.235

PERKI. (2019). Henti Jantung. Trinurhilawati, T., Martiningsih, M., Hendari, R. and Wulandari, A., 2019. Pengetahuan Bantuan Hidup Dasar dan Keterampilan Tindakan Recovery Position Pada Kader Siaga Bencana. Jurnal Keperawatan Terpadu (Integrated Nursing Journal), 1(1), pp.78-85. 